\title{
Differential expression of milk protein genes during lactation in the common brushtail possum (Trichosurus vulpecula)
}

\section{J Demmer, I K Ross, M R Ginger, C K Piotte and M R Grigor}

Department of Biochemistry, University of Otago, Box 56, Dunedin, New Zealand

(Requests for offprints should be addressed to J Demmer)

(J Demmer and M R Grigor are now at Dairy Science Group, AgResearch Ruakura, Private Bag 3123,

Hamilton, New Zealand)

\begin{abstract}
In the common brushtail possum (Trichosurus vulpecula) lactation lasts for 200 days and consists of two distinct phases. Milk composition changes dramatically between phase 2 and 3, which correspond to early and late lactation respectively (phase 1 corresponds to pregnancy). RNA expression patterns have been established for eight major milk protein genes throughout lactation in possum mammary glands. The levels of mRNA expressed from two genes, encoding the early and late lactation proteins, were differentially regulated during lactation, with peak RNA levels occurring in phase 2 and 3 of lactation respectively. Expression of these two RNA transcripts did not overlap, and neither gene was expressed at significant levels
\end{abstract}

between days 116 to 125 , suggesting that the transition from phase 2 to phase 3 of lactation occurs at this time. The level of lysozyme, $\alpha$-lactalbumin and trichosurin mRNA increased in phase 3 of lactation, whereas the levels of $\beta$-lactoglobulin, $\alpha$-casein and $\beta$-casein mRNA remained constant throughout lactation. In the non-suckled gland, expression of milk protein genes was greatly reduced by day 6 of lactation. In conclusion, the early and late lactation protein genes are good markers for phase 2 and 3 of lactation, with the transition between these phases occurring around day 120 of lactation in the possum.

Fournal of Molecular Endocrinology (1998) 20, 37-44

\section{INTRODUCTION}

Reproduction in marsupials is typified by a short gestation followed by a prolonged period of lactation. The female marsupial gives birth before the end of the oestrous cycle, and the mammary glands are 'prepared' for lactation during every cycle (termed phase 1 of lactation). In the common brushtail possum (Trichosurus vulpecula), pregnancy lasts for 17 days and following birth the small pouch young (weight $200 \mathrm{mg}$ ) crawls from the uterus and attaches on to one of two nipples in the pouch and suckles continuously for about 90 days (Sharman 1962). Lactation is induced only in the mammary gland associated with the nipple being suckled, whereas the non-suckled gland regresses shortly after the initiation of lactation (Sharman 1962). The composition of milk secreted from the gland at this stage of lactation (phase 2) has a high carbohydrate content (up to $10 \%$ ) but low levels of fat $(2-3 \%$;
Cowan 1989). The transition from phase 2 to 3 of lactation appears to coincide with the pouch young suckling intermittently and the time when the young first leave the pouch. The milk composition begins to change during a 'switch' phase (around day 90 to 110) with the level of milk solids increasing. Milk fat concentration increases to $6-8 \%$ while carbohydrate levels decrease to 4\% (Cowan 1989). There is only a slight increase in total milk protein concentration from 4 to $6 \%$ between phase 2 to 3 of lactation (Cowan 1989, Grigor et al. 1991). The milk produced during phase 3 of lactation is similar in composition to that of eutherian animals such as ruminants. In phase 3 of lactation, milk production is at a peak and growth of the pouch young is greatest. We have recently cloned cDNAs for eight different milk protein genes which are abundantly expressed in the possum mammary gland (Piotte \& Grigor 1996, Piotte et al. $1997 a, b$, M R Ginger \& M R Grigor, unpublished 
observations). Some of these genes are homologues of proteins found in the milk of eutherian mammals, e.g. $\beta$-lactoglobulin, $\alpha$-lactalbumin, lysozyme, $\alpha$ and $\beta$-casein. In addition to these, there are three novel possum milk protein genes: early lactation protein, trichosurin and late lactation protein. The early lactation protein has sequence homology with the Kunitz family of protease inhibitors (Piotte \& Grigor 1996) whereas late lactation protein and trichosurin, along with $\beta$-lactoglobulin, belong to the lipocalin family of secretory ligand-binding proteins (Piotte et al. 1997a). The possum late lactation protein is a homologue of a tammar wallaby (Macropus eugenii) whey protein which is only expressed in phase 3 of lactation (Nicholas et al. 1987, Collet et al. 1989). It has not yet been determined whether other marsupials express either trichosurin or early lactation protein. The biological role of these novel milk proteins in either the milk, mammary gland or rearing of the pouch young has not been established.

To date, the pattern of RNA expression for whey protein and casein genes during lactation has not been determined for the possum. Gel electrophoresis studies of possum milk proteins, carried out on a limited number of samples, showed that early lactation protein, late lactation protein and transferrin are differentially expressed between phase 2 and 3 of lactation (Grigor et al. 1991, Piotte \& Grigor 1996, Piotte et al. 1997a). The aim of this study was to determine the developmental expression pattern of eight major milk protein genes throughout lactation in the possum using RNA slot blotting techniques. This study has confirmed the differential expression of the early and late lactation proteins between phase 2 and 3 of lactation, and has established the time at which this switch in expression between these two genes occurs.

\section{MATERIALS AND METHODS}

\section{Collection of tissues}

Lactating mammary glands were collected from 35 feral common brushtail possums ( $T$. vulpecula) that were trapped at either Invermay (Mosgiel, Otago, New Zealand) or the Hutt Valley (Wellington, New Zealand). Animals were trapped at night and traps were cleared the following morning, when the possums were killed and the mammary gland dissected. The mammary glands collected covered days 1 to 190 of lactation in the possum. Non-suckled, non-lactating glands were collected from seven animals (trapped at Invermay) at day $1 \cdot 5,6,65,131,146,151$ and 161 of lactation. Identifying lactating and non-lactating glands was straightforward as pouch young remain attached to the nipple during early lactation and in late lactation the suckled gland is much greater in size than the non-suckled gland. The glands were rapidly dissected from the trapped possums, snap frozen on dry ice or in liquid nitrogen and stored at $-70{ }^{\circ} \mathrm{C}$. The stage of lactation for each animal was determined from the crown-rump length of the pouch young or back rider with the mother at time of capture, using the nomogram of Lyne and Verhagen (1957).

\section{RNA isolation}

Frozen tissues were ground to a powder under liquid nitrogen using a mortar and pestle. The RNA was extracted from the ground tissues by the guanidinium acid-phenol-chloroform method as described by Chomczynski \& Sacchi (1987).

\section{DNA and RNA probes}

The cDNA probes used in these experiments were: early lactation protein (Piotte \& Grigor 1996), late lactation protein, trichosurin, $\beta$-lactoglobulin (Piotte et al. 1997a), lysozyme and $\alpha$ - lactalbumin (Piotte et al. 1997b), $\alpha$ - and $\beta$-casein (M R Ginger \& M R Grigor, unpublished observations). Plasmid DNA from each of the clones was digested with restriction endonucleases and the DNA insert was purified by agarose gel electrophoresis. The purified DNA insert was then radiolabelled with $\left[\alpha-{ }^{32} \mathrm{P}\right] \mathrm{dCTP}$ (Amersham, Aylesbury, UK) using a random primer DNA labelling kit (Rediprime; Amersham). The radiolabelled probes were added directly to the hybridisation solution.

The rRNA probe was made by incubating $2 \mu \mathrm{g}$ possum liver total RNA in a first-strand cDNA synthesis reaction using random hexamer primers (Boehringer, Mannheim, Germany) and Superscript II reverse transcriptase (Gibco-BRL, Gaithersburg, MD, USA), as recommended by the manufacturer. The dNTP mixture used in the reaction consisted of dATP, dGTP, dTTP and $\left[\alpha-{ }^{32} \mathrm{P}\right] \mathrm{dCTP}$. The radiolabelled rRNA probe was added to the hybridisation solution with $400 \mu \mathrm{g}$ unlabelled possum liver RNA to ensure even hybridisation to all the RNA samples and to eliminate the effect of any labelled mRNAs common to possum mammary gland and liver.

\section{RNA slot blots}

Slot blot hybridisations followed the procedures described by Sambrook et al. (1989). Briefly, for each slot $5 \mu \mathrm{g}$ total RNA was denatured by heating 
to $65^{\circ} \mathrm{C}$ for $15 \mathrm{~min}$ in the presence of formaldehyde and formamide. Tubes were chilled briefly on ice, and 2 volumes $20 \times \mathrm{SSC}$ (containing 0.01 volume RNA loading dye) was added to each sample. The diluted, denatured RNA samples were loaded on to a slot blot apparatus $(3 \times 30$ wells; SRC $072 / 0$; Schleicher and Schuell, Dassel, Germany) containing a Hybond $\mathrm{N}$ membrane (Amersham). The RNA was fixed on to the Hybond $\mathrm{N}$ membrane by $\mathrm{UV}$ cross-linking (Stratalinker; Stratagene, La Jolla, CA, USA). Membranes were pre-hybridised in Denhardt's hybridisation solution (Sambrook et al. 1989) at $60{ }^{\circ} \mathrm{C}$ for $1 \mathrm{~h}$, after which the radiolabelled DNA probes were added in fresh hybridisation solution. Hybridisations were carried out overnight at $60{ }^{\circ} \mathrm{C}$, and were followed by stringency washes $(2 \times \mathrm{SSPE}, \quad 0 \cdot 1 \%$ SDS for $15 \mathrm{~min}$ twice, and $1 \times \mathrm{SSPE}, 0 \cdot 1 \% \mathrm{SDS}$ for $15 \mathrm{~min}$ ). Following the stringency washes the slot blot membranes were exposed to PhosphoImager screens (Fuji) for several hours. These screens were then scanned with a PhosphoImager (Fuji BAS-1500), and images were analysed using MacBAS (ver2.0) software (Fujifilm Co, Tokyo, Japan). Along with the mammary gland RNA samples, each membrane had one slot containing $5 \mu \mathrm{g}$ possum liver total RNA. The liver sample was used to calculate the amount of background hybridisation for each experiment. Because none of the milk protein genes hybridise to liver mRNAs, the level of background hybridisation was extremely low. Expression of the milk protein genes is very high in the mammary gland requiring short exposure times to the PhosphoImager screens. There was no cross reaction with any of the probes to rRNA in Northern blots. In addition, the background signal generated by the membrane on the PhosphoImager screens was measured and subsequently subtracted from all readings. The amount of RNA loaded in each slot was measured by hybridising an $\left[\alpha-{ }^{32} \mathrm{P}\right] \mathrm{dCTP}$ radiolabelled total RNA probe to each of the slot blot membranes. Hybridisations and stringency washes for the rRNA probe were the same as for the cDNA probes, after which blots were exposed to PhosphoImager screens and then scanned as before. The numerical values obtained for a particular milk protein gene were normalised to the amount of rRNA detected in that 'slot', giving a 'relative RNA expression level'. Because the two data sets for each gene were similar the results presented are the average of the two independent analyses.

\section{Northern blotting}

Total RNA $(2.5 \mu \mathrm{g})$ was resolved by gel electrophoresis in $1 \cdot 2 \%$ agarose, $0.6 \mathrm{M}$ formaldehyde gels (Sambrook et al. 1989) and transferred on to Hybond $\mathrm{N}$ membrane. The RNA was fixed on to the Hybond $\mathrm{N}$ membrane by UV cross-linking (Stratalinker; Stratagene). Northern blots were hybridised overnight at $60{ }^{\circ} \mathrm{C}$ with ${ }^{32} \mathrm{P}$-radiolabelled DNA probes in Denhardt's hybridisation solutions (Sambrook et al. 1989) following a prehybridisation in the same solution for $1 \mathrm{~h}$. The blots were washed twice in $2 \times \mathrm{SSPE}, 0.1 \% \mathrm{SDS}$ at $60{ }^{\circ} \mathrm{C}$ for $15 \mathrm{~min}$, followed by one wash in $1 \times \mathrm{SSPE}, 0 \cdot 1 \%$ SDS for $15 \mathrm{~min}$. Membranes were placed in autoradiograph cassettes and exposed to Kodak X-OMAT AR film at room temperature. Northern blots were used to confirm the quality of the RNA, determine the number of transcripts for each gene and to evaluate whether any of the probes cross-hybridised with rRNA.

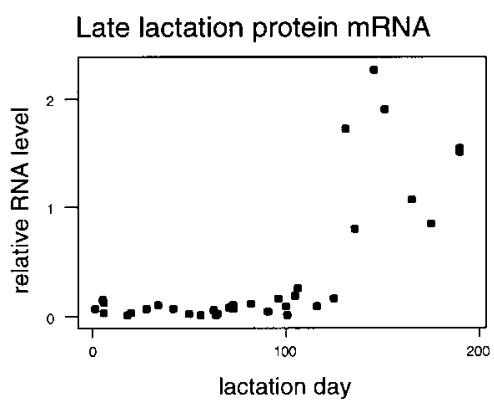

FIGURE 1. Scatterplots of the relative levels of early and late lactation protein mRNA in possum mammary glands during lactation. Slot blots of RNA isolated from the mammary glands of lactating possums $(n=35)$ were hybridised with radiolabelled cDNA probes for early lactation protein and late lactation protein, as described in Materials and Methods. The level of RNA was determined relative to the amount of rRNA present in each sample. Values plotted are the average of two independent analyses. 


\section{Statistical analysis}

To determine whether there was a significant difference in the relative RNA expression levels between phase 2 and 3 of lactation, values for each gene were pooled into early lactation (day 1-119 of lactation, $n=26)$ or late lactation ( $>120$ days of lactation, $n=9$ ). A two-sample $t$-test (Minitab Statistics computer program) was used to determine the statistical significance of any differences between the two means.

\section{RESULTS}

The RNA slot blotting technique was used to determine the pattern of mRNA expression for eight major milk protein genes in the lactating mammary gland of possums. For each gene the relative RNA expression level was determined for every animal in the study. The same technique was used to determine RNA expression in the nonsuckled glands of some of the animals. To establish whether there was a significant change in mRNA levels between phase 2 and 3 of lactation, the mean relative RNA expression level was determined for all the animals in a particular phase. These means were statistically analysed.

Levels of early lactation protein mRNA increased after parturition, reaching a peak between days 40 and 60 of lactation before decreasing around day 80 of lactation (Fig. 1). Early lactation protein mRNA was difficult to detect after day 116 of lactation by either Northern or slot blotting techniques (Figs 1 and 2), but could be detected by PCR in some of the late lactation RNA samples (results not shown). In contrast, expression of late lactation protein mRNA was greatest after day 130 of lactation (Fig. 1). Unlike early lactation protein RNA, there was no clear pattern of late lactation protein RNA expression in phase 3 of lactation. Lower levels of late lactation protein $\mathrm{mRNA}$ were detected during early stages of lactation by both slot blots (Fig. 1) and PCR (data not shown), but not by Northern blotting (Fig. 2). The early lactation protein and late lactation protein genes were transcribed at significantly different levels $(P<0 \cdot 001)$ between phase 2 and 3 of lactation (Table 1), with peak levels of mRNA expression for the early and late lactation protein being associated with phase 2 and 3 of lactation respectively.

There were two samples, days 116 and 125 of lactation, in which the expression of both genes was very low, suggesting the presence of a 'switch-over' phase at this time (Figs 1 and 2). Interestingly, RNA levels for trichosurin and both caseins was also low in these two samples, whereas the levels of

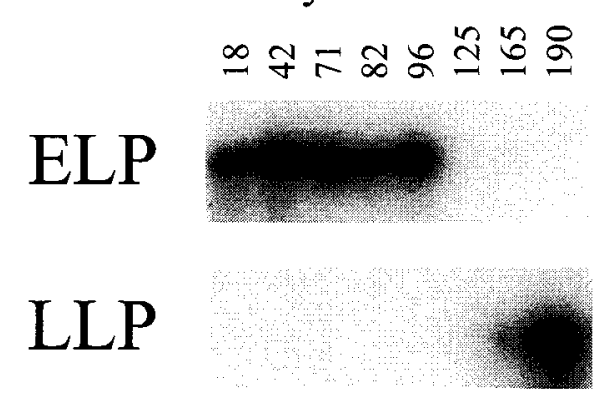

\section{Lysozyme}

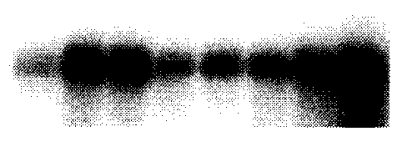

\section{Trichosurin}

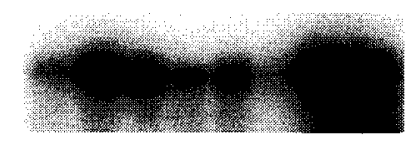

\section{rRNA}

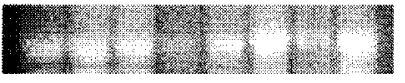

FIGURE 2. Northern blots of possum mammary gland RNA hybridised with early lactation protein, late lactation protein, lysozyme and trichosurin $\mathrm{cDNA}$ probes. Autoradiographs of the Northern blots hybridised with the early lactation protein (ELP), late lactation protein (LLP), lysozyme, and trichosurin are shown. The ethidium bromide stained gel showing the $18 \mathrm{~S}$ rRNA indicates the amount of RNA loaded for each sample. Lanes 1-8 contained possum mammary gland total RNA ( $2 \cdot 5 \mu \mathrm{g} / \mathrm{lane})$ from days $18,42,71,82,96$, 125,165 and 190 of lactation respectively.

$\beta$-lactoglobulin, $\alpha$-lactalbumin and lysozyme RNA were similar to those in other animals (Figs 2 and 3).

Lysozyme mRNA was initially expressed at low levels which continued to increase throughout lactation (Fig. 3). There was a significant increase $(P<0 \cdot 05)$ in lysozyme mRNA levels from phase 2 to 3 of lactation (Table 1). Considerable variation was observed in the amount of lysozyme mRNA detected in individual animals (Figs 2 and 3). RNA from the $\alpha$-lactalbumin gene was expressed at a constant rate up to day 120 of lactation, after which there was a small significant $(P<0 \cdot 05)$ increase in mRNA levels during phase 3 of lactation (Fig. 3; Table 1). Expression of trichosurin RNA increased throughout lactation with peak levels present in late lactation (Figs 2 and 3). The differences in trichosurin mRNA levels between phase 2 and 3 were significantly different $(P<0 \cdot 05$; Table 1$)$. The expression pattern for the $\beta$-lactoglobulin gene remained constant throughout lactation (Fig. 3) 
TABLE 1. RNA levels (means \pm s.E.M.) of eight milk protein genes in phase 2 (days $1-120$ of lactation, $n=26$ ) and phase 3 (days 120-190, $n=9$ ) mammary glands of lactating possums. Relative RNA levels determined for each gene in every animal are displayed as scatterplots in Figs 1 and 3

\section{Gene}

$\alpha$-Lactalbumin

$\beta$-Lactoglobulin

Early lactation protein

Late lactation protein

Trichosurin

Lysozyme

$\alpha$-Casein

$\beta$-Casein

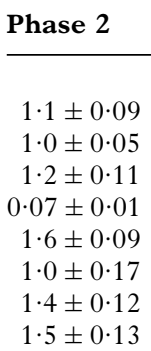

\begin{tabular}{|c|c|}
\hline Phase 3 & $P$ \\
\hline $2 \cdot 3 \pm 0 \cdot 41$ & $<0.05$ \\
\hline $1 \cdot 6 \pm 0 \cdot 29$ & 0.062 \\
\hline $0 \cdot 02 \pm 0 \cdot 01$ & $<0 \cdot 001$ \\
\hline $1 \cdot 3 \pm 0 \cdot 22$ & $<0 \cdot 001$ \\
\hline $2 \cdot 2 \pm 0 \cdot 22$ & $<0.05$ \\
\hline $2 \cdot 3 \pm 0 \cdot 52$ & $<0.05$ \\
\hline $1 \cdot 9 \pm 0 \cdot 25$ & $0 \cdot 14$ \\
\hline $1 \cdot 6 \pm 0 \cdot 26$ & $0 \cdot 83$ \\
\hline
\end{tabular}

with there being no significant difference in mRNA levels between phase 2 and 3 . The expression of $\alpha$-casein and $\beta$-casein mRNA was extremely variable between individual animals and the levels of mRNA detected did not appear to follow any pattern through lactation. The ratio of $\alpha$-casein to $\beta$-casein mRNA levels for a particular animal was, however, constant at a value of $0.96( \pm 0.07)$ for all of the animals ( $n=35$; results not shown). There was no significant difference in $\alpha$-casein and $\beta$-casein mRNA levels between phase 2 and 3 of lactation (Table 1).

Following birth, lactation is only initiated in the suckled gland, whereas the non-suckled gland regresses and reduces in weight soon after parturition (Sharman 1962). What effect this regression of the non-suckled gland has on milk protein gene expression is not known. RNA was isolated from both the suckled and non-suckled glands from seven individual animals at different stages of lactation (i.e. one animal each at day $1 \cdot 5,6,65,131,146,151$ and 161). The RNA was analysed by the slot blotting procedure as described above. In the day 1.5 sample, the level of RNA for all the milk protein genes was similar in both the suckled and non-suckled glands (Table 2). By day 6 of lactation, the level of mRNA for all the genes had decreased to low levels in the non-lactating gland (Table 2). The non-suckled glands collected from the day 65 , 131, 146, 151 and 161 animals contained no milk protein gene mRNA. The late lactation protein gene, which is not expressed at detectable levels during early lactation, was not detected in any of the non-lactating glands. Levels of late lactation protein RNA increased in the suckled gland during phase 3 of lactation (Fig. 1), but there was no induction of late lactation protein expression in the non-suckled glands collected from animals at days 131, 146, 151 and 161 of lactation (data not shown).

\section{DISCUSSION}

This study has established the mRNA expression pattern for eight of the major milk protein genes during lactation in the possum. The most intriguing result is the differential expression of early and late lactation protein mRNA between phases 2 and 3 of lactation respectively. High levels of mRNA from both genes were never detected in the same sample, indicating that early and late lactation protein mRNAs are good markers for distinguishing between phase 2 and 3 of lactation. These results suggest that transcription of these two genes is differentially regulated between phase 2 and 3 of lactation in the possum mammary gland. Neither gene transcript was expressed at significant levels between days 116 and 125 of lactation, suggesting that there is a 'switch-phase' at this time, during which the change in milk composition occurs. The levels of early lactation protein mRNA started to decrease at day 80 of lactation which coincides with a surge in mammary gland growth at this time (Tyndale-Biscoe \& Renfree 1987). These differences in the levels of the early and late lactation protein mRNAs are supported by observations made from 2-dimensional gel electrophoresis studies of whey proteins isolated from phase 2 and 3 possum milk (Piotte \& Grigor 1996, Piotte et al. 1997a). The dramatic changes in the levels of early and late lactation protein mRNA suggests that this is regulated at the level of transcription rather than mRNA stability. To confirm this hypothesis, however, will require nuclear run-on assays to be performed.

In the tammar wallaby ( $M$. eugenii), the late lactation protein is first detected in milk at day 180 of lactation, after which its concentration in milk increases rapidly, reaching a peak at day 250 of lactation (Nicholas et al. 1987). Furthermore, late 

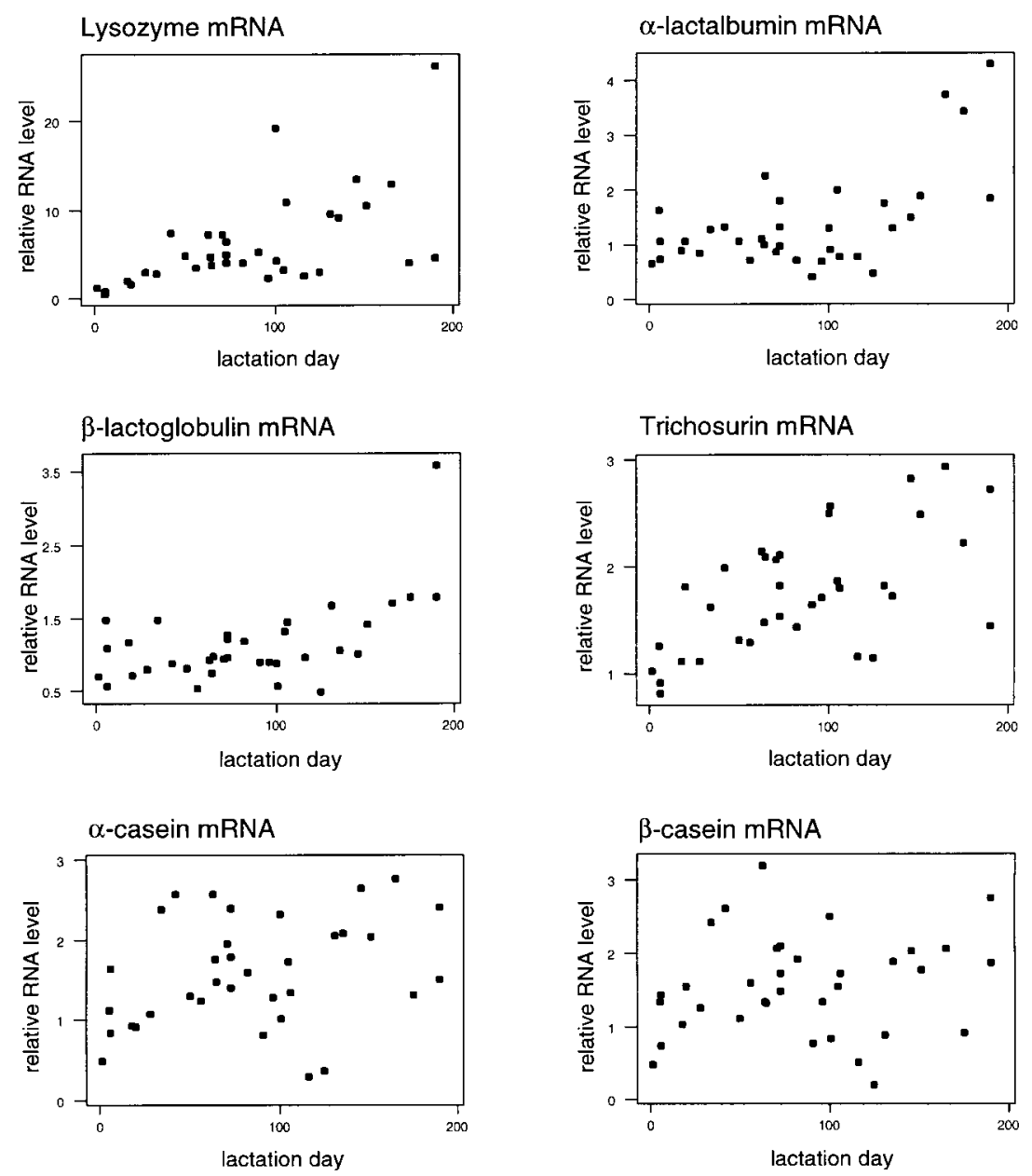

FIGURE 3. Scatterplots of the relative RNA levels of the lysozyme, $\alpha$-lactalbumin, $\beta$-lactoglobulin, trichosurin, $\alpha$-casein and $\beta$-casein genes in the possum mammary gland during lactation. Slot blots of RNA isolated from the mammary glands of lactating possum $(n=35)$ were hybridised with radiolabelled cDNA probes for lysozyme, $\alpha$-lactalbumin, $\beta$-lactoglobulin, trichosurin, $\alpha$-casein and $\beta$-casein, as described in Materials and Methods. The level of RNA was determined relative to the amount of rRNA present in each sample. Values plotted are the average of two independent analyses.

lactation protein RNA was expressed at low levels on day 172 of lactation in the wallaby, but reached a peak on day 239 (Bird et al. 1994). Expression of the late lactation protein in both the possum and the wallaby coincides with the transition from phase 2 to 3 of lactation.

In contrast to the early and late lactation protein genes, RNA transcripts for the trichosurin, $\beta$-lactoglobulin, lysozyme, $\alpha$-lactalbumin, $\alpha$ - and $\beta$-casein genes were detected throughout lactation. Expression of the possum lysozyme gene continued to increase throughout lactation but levels were variable between animals. The lysozyme protein is thought to have bactericidal properties and the pouch young would benefit from such a protein throughout lactation, especially when the young leave the pouch for the first time. In the ringtail possum (Pseudocheirus peregrinus), lysozyme is a late (phase 3) lactation protein and is not detected in milk until after day 112 of lactation (Nicholas et al. 1989). This is in contrast to the brushtail possum where the lysozyme mRNA and protein are expressed throughout lactation (Piotte et al. 1997b). The appearance of lysozyme in the milk of ringtail possums coincides with initiation of coprophagy in the young. 
TABLE. 2. Relative RNA levels at days $1 \cdot 5$ and 6 of lactation for seven milk protein genes in the suckled and non-suckled mammary glands from possums (values have not been included for late lactation protein as these were not above background in samples analysed). Values are the average of two independent analyses, normalised to the amount of rRNA present in each sample

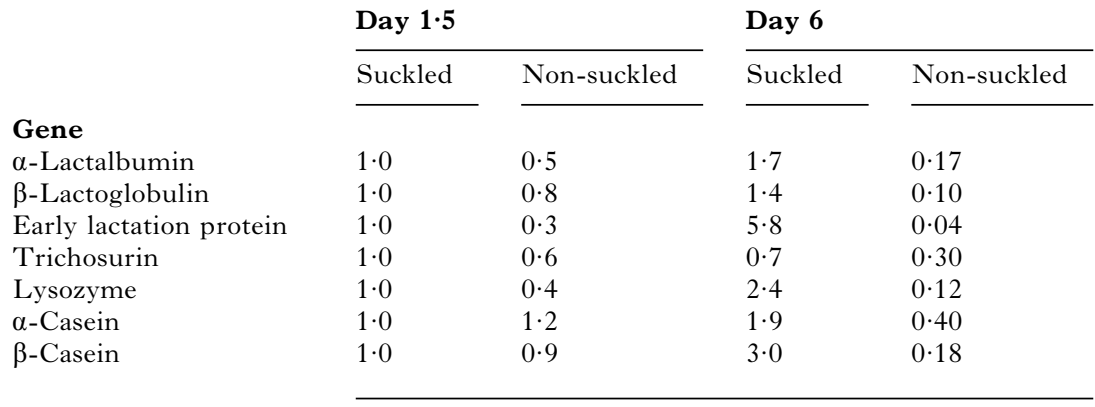

There were modest increases in $\alpha$-lactalbumin and trichosurin RNA levels during phase 3 of lactation. These small increases in whey protein $\mathrm{mRNA}$ in phase 3 of lactation coincide with peak milk synthesis in the possum. Milk protein concentration increases during phase 3 of lactation and this is due to an increase in whey proteins but not caseins (Grigor et al. 1991, M R Ginger \& M R Grigor, unpublished observations). The concentration of the $\alpha$-lactalbumin protein in the milk of brushtail possums increased 2 -fold during phase 2 of lactation, but did not change after day 80 (Grigor et al. 1991). The level of $\alpha$-lactalbumin mRNA observed in the mammary gland therefore does not appear to be directly related to the concentration of the $\alpha$-lactalbumin protein in possum milk. In the tammar wallaby, levels of $\alpha$-lactalbumin protein and mRNA remained constant throughout lactation (Messer \& Elliott 1987, Bird et al. 1994). Similarly, concentration of $\alpha$-lactalbumin in the milk of the ringtail possum is constant throughout lactation (Nicholas et al. 1989). Levels of $\beta$-lactoglobulin mRNA in the wallaby increased by $50 \%$ during phase 3 to reach a peak at day 239 before decreasing again in late lactation (Bird et al. 1994). This increase, however, was not observed in the brushtail possum.

Both the $\alpha$-casein and $\beta$-casein genes are expressed at a constant rate throughout lactation in the brushtail possum, and a similar observation has been made for casein concentration in possum milk (M R Ginger \& M R Grigor, unpublished observations). Although there appeared to be considerable variation between animals in the levels of casein mRNA, the ratio of $\alpha$-casein to $\beta$-casein mRNA remained close to $1: 1$ in all animals tested, suggesting tight regulation of casein gene transcription in the possum. In the wallaby $\alpha$-casein RNA levels were constant throughout lactation, whereas the level of $\beta$-casein RNA increased by $80 \%$ during phase 3 of lactation, reaching a peak at day 239 before decreasing later in lactation (Bird et al. 1994). This increase in $\beta$-casein RNA was reflected by an increase in $\beta$-casein protein concentration in wallaby milk (Nicholas et al. 1995).

RNA levels of all of the milk protein genes decreased to low levels by day 6 of lactation in the non-suckled gland. This indicates that the lactating gland continues to function independently of the non-suckled gland, which enters a quiescent phase. In the tammar wallaby, where a mother can suckle two young at different stages of development and lactation, at the same time, the two non-suckled glands also enter a quiescent phase (Nicholas 1988). Suckling is therefore a crucial stimulus for initiating and maintaining lactation in both the possum and wallaby, and the lactogenic signals present in the serum of the lactating female do not appear to affect the non-suckled gland. This was illustrated by the lack of late lactation protein mRNA in the non-suckled mammary glands in phase 3 animals.

These experiments have established that mRNA of the early and late lactation protein genes are useful as markers of phase 2 and 3 of lactation respectively, and that there is a transition/switch phase between days 116 to 125 of lactation. Expression of RNA from the other whey protein and the casein genes was relatively constant throughout lactation.

\section{ACKNOWLEDGEMENTS}

We would like to thank Dr Doug Eckery of AgResearch Wallaceville (Upper Hutt, NZ) and Dr Bernie McLeod of AgResearch Invermay (Mosgiel, NZ) for supplying possum mammary gland 
samples, and Dr Harold Henderson of AgResearch Ruakura (Hamilton, NZ) for assistance with statistical analysis. J Demmer, I Ross and C Piotte were supported by New Zealand Foundation of Research Science and Technology grants. M Ginger was supported by a NZ MAF Policy grant.

\section{REFERENCES}

Bird PH, Hendry KA, Shaw DC, Wilde CJ \& Nicholas KR 1994 Progressive changes in milk protein gene expression and prolactin binding during lactation in the tammar wallaby (Macropus eugenii). Fournal of Molecular Endocrinology 13 117-125.

Chomczynski P \& Sacchi N 1987 Single-step method of RNA isolation by acid guanidinium thiocyanate-phenolchloroform extraction. Analytical Biochemistry 162 156-159.

Collet C, Joseph R \& Nicholas K 1989 Molecular cloning and characterization of a novel marsupial milk protein gene. Biochemical and Biophysical Research Communications 164 1380-1383.

Cowan PE 1989 Changes in milk composition during lactation in the common brushtail possum, Trichosurus vulpecula (Marsupialia: Phalangeridae). Reproduction, Fertility and Development 1 325-335.

Grigor MR, Bennett BL, Carne A \& Cowan PE 1991 Whey proteins of the common brushtail possum (Trichosurus vulpecula): isolation, characterization and changes in concentration in milk during lactation of transferrin, alphalactalbumin and serum albumin. Comparative Biochemistry and Physiology 98 451-459.

Lyne AG \& Verhagen AMW 1957 Growth of the marsupial Trichosurus vulpecula and a comparison with some higher mammals. Growth 21 167-195.

Messer M \& Elliott C 1987 Changes in alpha-lactalbumin, total lactose, UDP-galactose hydrolase and other factors in tammar wallaby (Macropus eugenii) milk during lactation. Australian Fournal of Biological Sciences 40 37-46.
Nicholas KR 1988 Asynchronous dual lactation in a marsupial, the tammar wallaby (Macropus eugenii). Biochemical and Biophysical Research Communications 154 529-536.

Nicholas KR, Messer M, Elliott C, Maher F \& Shaw DC 1987 A novel whey protein synthesized only in late lactation by the mammary gland from the tammar (Macropus eugenii). Biochemical fournal 241 899-904.

Nicholas K, Loughnan M, Messer M, Munks S, Griffiths M \& Shaw D 1989 Isolation, partial sequence and asynchronous appearance during lactation of lysozyme and alphalactalbumin in the milk of a marsupial, the common ringtail possum (Pseudocheirus peregrinus). Comparative Biochemistry and Physiology 94 775-778.

Nicholas K, Wilde C, Bird P, Hendry K, Tregenza K \& Warner B 1995 Asynchronous concurrent secretion of milk proteins in the Tammar wallaby (Macropus eugenii). In Intercellular Signalling in the Mammary Gland, pp 153-170. Eds C Wilde, M Peaker \& C Knight. New York: Plenum Press.

Piotte CP \& Grigor MR 1996 A novel marsupial protein expressed by the mammary gland only during the early lactation and related to the Kunitz proteinase inhibitors. Archives of Biochemistry and Biophysics 330 59-64.

Piotte CP, Hunter AK, Marshall CJ \& Grigor MR $1997 a$ Phylogenetic analysis of the three lipocalins present in the milk of Trichosurus vulpecula (Phalangeridae, Marsupialia). Fournal of Molecular Evolution (In Press).

Piotte CP, Marshall CJ, Hubbard MJ, Collet C \& Grigor MR $1997 b$ Lysozyme and $\alpha$-lactalbumin from the milk of a Marsupial, the Common Brushtailed possum (Trichosurus vulpecula). Biochimica et Biophysica Acta 1336 235-242.

Sambrook J, Fritsch EF \& Maniatis T 1989. Molecular Cloning: a Laboratory Manual, edn 2. New York: Cold Spring Harbor Laboratory Press.

Sharman G 1962 The initiation and maintenance of lactation in a marsupial, Trichosurus vulpecula. Fournal of Endocrinology 25 375-385.

Tyndale-Biscoe H \& Renfree M 1987 Monographs on Marsupial Reproduction: Reproductive Physiology of Marsupials, pp 343-372. Cambridge: Cambridge University Press.

RECEIVED 2 June 1997 